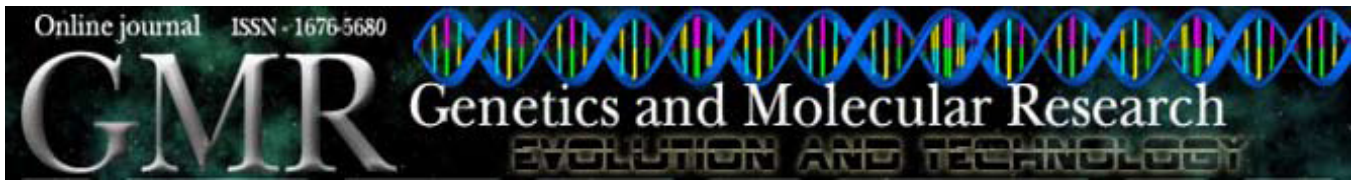

Short Communication

\title{
Preliminary analysis of expressed sequences of genes in Genipa americana L. plant roots exposed to cadmium in nutrient solution
}

\author{
V.L. Souza, A.-A.F. Almeida, B.T. Hora Júnior, A.S. Gesteira \\ and J.C.M. Cascardo \\ Departamento de Ciências Biológicas, \\ Universidade Estadual de Santa Cruz, Ilhéus, BA, Brasil \\ Corresponding author: A.-A.F. Almeida \\ E-mail: alexalan@uesc.br
}

Genet. Mol. Res. 7 (4): 1282-1288 (2008)

Received September 1, 2008

Accepted September 22, 2008

Published November 18, 2008

\begin{abstract}
Many cell functions are redundantly executed in cells, and the experimental approaches that analyze the group of proteins, whose expression is modified in a specific functional condition, enable the identification of the group of proteins that are expressed under stress conditions. The objective of the present study was the evaluation of the genetic expression induced by cadmium $(\mathrm{Cd})$ in Genipa americana L. (Rubiaceae) plants cultivated in nutritive solution, in order to help further studies concerning its use as a plant phytoremediator of such a metallic element. Plants were exposed to increasing concentrations of $\mathrm{Cd}(0.5,1,2,4,8$, and $16 \mathrm{mg} / \mathrm{L})$, together with the control, in nutritive solution. After the application of the treatments, root tips were harvested for the construction of a cDNA library. Of the 165 expressed sequence tags (ESTs) generated with the construction of the cDNA library, 81 showed homology to genes deposited in the NCBI database, 67 did not show similarity to any available gene, and 17 ESTs
\end{abstract}


demonstrated homology with unknown genes. Of the most abundant cDNAs, 16 ESTs were similar to sequences of metallothionein genes. The analysis of ESTs, obtained from the root of $G$. americana through the construction of a cDNA library, allowed the identification of genes probably associated with proteins and enzymes related to the defense mechanisms of plants when they undergo biotic and abiotic stresses.

Key words: cDNA; Heavy metal; Expressed sequence tags; Woody plant

\section{INTRODUCTION}

The use of phosphate fertilizers and sewage wastes in agriculture, as well as in industries, are considered to be the main causes of cadmium $(\mathrm{Cd})$ dispersion in food and in the environment (Dickinson and Pulford, 2005). Plant exposure to high concentrations of Cd causes oxidative stress, which, with the lack of protection mechanisms, may cause the oxidation of proteins and lipids of cell membranes, or even, damage to DNA (Chaoui and El Ferjani, 2005). However, different tolerance mechanisms may act together in order to inhibit the phytotoxic effects of $\mathrm{Cd}$ in plant species. These mechanisms include the chelation and sequestration of heavy metals by particular ligands. Chelating agents include amino acids, organic acids and two classes of peptides, the phytochelatins and metallothioneins (MT) (Cobbett and Goldsbrough, 2002; Almeida et al., 2007).

In plants under stress caused by abiotic factors such as heavy metals, it is possible to identify genes expressed under such conditions, through the construction of cDNA libraries. The first step for categorizing and cataloging genetically the responses to abiotic stress is the discovery of genes, through partial sequencing, of clones of cDNA or expressed sequence tags (ESTs) on a large scale; it is a fast method for isolating genes when compared to genomic sequencing (Zhang et al., 2001). The ESTs generated by this procedure may be compared with databases of identified genes. The result of the comparisons is used as a guide to define putative identifications to the cDNAs. Through the putative identifications of the ESTs, specific genes may be selected for further studies. This methodology leads to rapid gene identification in several organisms and accelerates research by providing genetic material for further investigations (Covitz et al., 1998).

Genipa americana is a Neotropical woody species belonging to the family Rubiaceae and is usually found in moist, soaked or flooded soils, near river banks. It is found from Mexico to Argentina (Mielke et al., 2003). Due to its capacity for tolerating soil inundation, it is recommended for the reforestation of areas located near rivers and areas that are frequently flooded (Mielke et al., 2003). Additionally, this woody species also shows great potential as a phytoremediator, mainly as a rizofilterer and phytostabilizer of $\mathrm{Cr}^{3+}$ (Barbosa et al., 2007) and a rizofilterer of Cd (Souza VL, unpublished results).

In this study, we performed a preliminary analysis of a cDNA library constructed of $G$. americana root tips after exposure to different $\mathrm{Cd}$ concentrations in nutritive solution. Further studies, using the cDNA library, will allow the identification and the characterization of Cd tolerance-related genes to evaluate the potential of $G$. americana as a phytoremediator tree of $\mathrm{Cd}$ in contaminated watersheds. 


\section{MATERIAL AND METHODS}

\section{Growth conditions and plant material}

The experiment was conducted under greenhouse conditions at the Universidade Estadual de Santa Cruz (UESC), Ilhéus, BA, Brazil (1445'15"S, 39¹3'59'W, 40 a.m.s.1). Plants of G. americana, 2.8 years old were transplanted to polyethylene trays ( 8 plants/tray), with a capacity of $30 \mathrm{~L}$ each, containing half-strength Hoagland's solution (Hoagland and Arnon, 1950), where they remained for 70 days for acclimation. The solution was changed every 30 days and its volume was maintained by daily replacement with demineralized water, remaining under constant aeration. After the acclimation period, the nutritive solution was again changed and the treatments with increasing concentrations of $\mathrm{Cd}\left(0.5,1,2,4,8\right.$, and $16 \mathrm{mg} / \mathrm{L}$ ) as $\mathrm{CdCl}_{2} \cdot 5 / 2 \mathrm{H}_{2} \mathrm{O}$, together with the control (without $\mathrm{Cd}$ ) were initiated. During the whole experimental period, the solution's $\mathrm{pH}$ was monitored and adjusted to 5.9, using either $\mathrm{NaOH}$ or $\mathrm{HCl}$.

\section{RNA extraction and cDNA library construction}

Roots exposed to $16 \mathrm{mg} / \mathrm{L} \mathrm{Cd}$ were harvested after exposure of $0,6,12,24,48$, 72 , and $96 \mathrm{~h}$. Samples were stored at $-80^{\circ} \mathrm{C}$ after freezing in liquid nitrogen. Total RNA of roots, for the different harvesting periods, was extracted from frozen tissues as described by Gesteira et al. (2003), with some modifications. RNA was separated on 1\% DEPCtreated agarose gel and stained with ethidium bromide to confirm RNA integrity.

The RNA used to construct the cDNA library was treated with DNAse (Fermentas). Afterward, $5 \mu \mathrm{L}$ RNA from each period of exposure to $\mathrm{Cd}(6,12,24,48,72$, and $96 \mathrm{~h}$ ) were pooled. The library was constructed from pooled total RNA, using the kit Smart cDNA CREATOR as described by the manufacturer (Clontech). The cDNAs were cloned in the plasmid pGEM-T Easy A137A Electromax DH10 $\beta$ cells (Invitrogen), were transformed, and colonies picked and grown in 96-well microtiter plates, containing LB medium, ampicillin $(100 \mu \mathrm{g} / \mathrm{L})$ and $16 \%$ glycerol, which were stored at $-80^{\circ} \mathrm{C}$.

\section{Extraction of plasmid DNA and sequencing of cDNA clones}

Plasmid DNA was obtained from individual clones through the use of the alkaline lysis procedure according to Sambrook et al. (1989), adapted for 96-well plates. Plasmid quality and quantity were checked on 1\% TBE-BET agarose gel. For the library, 200 clones were randomly selected and sequenced from the 5' end by the DyEnamic ET Dye Terminator kit (MegaBACE, GE Health Care) method, and using the primer M13-F 5'-GTAAAACGACGGCCAGT-3' as forward primer. DNA sequencing was carried out by capillary sequencing using the MegaBACE 1000 (Amersham Biosciences - GE Health Care).

The sequences from electropherograms were trimmed to remove the vector using the program Vecscreen, part of the software BLAST available on the Internet (http://www. ncbi.nlm.nih.gov/VecScreen/VecScreen.html). After this process, just sequences longer than $90 \mathrm{bp}$ were considered. Each edited EST was translated into all six reading frames and compared with the database at the NBCI, using the BLASTx and tBLASTx programs 
(http://www.ncbi.nlm.nih.gov/BLAST/). The alignments that demonstrated similarity with an expected value less than or equal to $1.10^{-4}$ were considered to be significant. The probable identifications for ESTs were noted based on the results of BLAST research, information of gene ontology (http://www.geneontology.org/), and studies related to research area (Covitz et al., 1998; Zhang et al., 2001; Journet et al., 2002).

\section{RESULTS}

The generated sequences from the cDNA library of G. americana plant roots treated with $\mathrm{Cd}$ displayed an average size of $459 \mathrm{bp}$. Of the 200 randomly sequenced clones, after trimming for low quality, shortness $(<90 \mathrm{bp})$ and vector contamination, 165 sequences corresponded to the adopted quality criterion. The length of high-quality sequences ranged from 98 to $880 \mathrm{bp}$.

Of the 165 ESTs, 81 showed homology to genes identified and deposited in the NCBI database, 67 showed similarity to any available gene or displayed similarity with an E-value that was lower than the adopted standard value $\left(10^{-4}\right)$. The 17 remaining ESTs demonstrated homology to unknown genes. In the process of functional annotation, the probable coded proteins were grouped into nine functional categories according to the classification described by Covitz et al. (1998) (Table 1). The categories of primary metabolism and of defense were the categories that showed a predominance of putative genes. A significant number of sequences had homology to genes that encode proteins related to signal transduction, synthesis and protein processing. The ESTs corresponding to the most abundant cDNAs are listed in Table 2. Among them, 14 ESTs showed similarity to genes that code for MT characterized in the species Mimilus gutatus and 2 for MT IV of the species Plantago major. Furthermore, ESTs that were also frequent in the cDNA library belonged to the gene family related to pathogenesis (PR): PR4, PR10, $\beta$-1, 3-glycanase, and gene families of chitinase and peroxidase.

\section{DISCUSSION}

The root of G. americana is an important organ for the accumulation and stabilization of $\mathrm{Cr}^{3+}$ (Barbosa et al., 2007) and the accumulation of Cd (Souza VL, unpublished results). Understanding the mechanisms related to this process, mainly the identification of ligands that may sequester the metallic element to achieve tolerated levels, for the proper functioning of cell functions, is essential for the analysis of the potential of G. americana as phytoremediator of heavy metals. The RNA used in the construction of the cDNA library was from roots harvested in different periods of exposure of $\mathrm{G}$. americana to $\mathrm{Cd}$. In addition, during the period of exposure to the metal, the species demonstrated tolerance to 16 $\mathrm{mg} / \mathrm{L} \mathrm{Cd}$, which supported our choice of such a concentration for the construction of the cDNA library.

The multitude of putative genes that encode proteins related to the synthesis of cell wall, cytoskeleton, cell division, and other active processes during growth was expected, since it reflects the state of active growth of the tissue used to construct the library (Covitz et al., 1998; Zhang et al., 2001). The probable genes categorized in the functions of defense may be proper targets for study, considering the possible involvement of such genes in the tolerance mechanisms of G. americana to Cd stress. 
Table 1. Putative identification of expressed sequence tags generated and their grouping into 9 functional classes.

\begin{tabular}{|c|c|}
\hline Class & Functional annotation \\
\hline Cell wall structure and metabolism & $\begin{array}{l}\text { Proline-rich protein } \\
\text { Cinnamyl alcohol dehydrogenase }\end{array}$ \\
\hline Cytoskeleton & Actin \\
\hline Primary metabolism & $\begin{array}{l}\text { Cytochrome c oxidase subunit } \mathrm{Vb} \\
\text { Glyceraldehyde-3-phosphate dehydrogenase } \\
\text { Serine hydroxymethyltransferase } 1 \\
\text { S-adenosylmethionine synthetase } \\
\text { Aldo-keto reductase } \\
\text { Alpha-arabinosidase } 1 \\
\text { Monodehydroascorbate reductase } \\
\text { Photosystem I reaction center subunit II precursor } \\
\text { S-methyltransferase }\end{array}$ \\
\hline Gene expression and RNA metabolism & $\begin{array}{l}\text { GRAS transcription factor } \\
\text { RNA polymerase subunit isoform } \mathrm{V} \\
\text { Zinc finger protein }\end{array}$ \\
\hline Protein synthesis and processing & $\begin{array}{l}\text { Small subunit ribosomal RNA } \\
\text { Large subunit ribosomal RNA } \\
\text { 6-Domain trypsin inhibitor precursor } \\
\text { Serine carboxypeptidase } \\
\text { Translation initiation factor } 5 \mathrm{~A}-4 \\
\text { Ubiquitin-protein ligase }\end{array}$ \\
\hline Signal transduction & $\begin{array}{l}\text { GTP-binding protein } \\
\text { Protein phosphatase } 2 \mathrm{C} \\
\text { Calmodulin binding } \\
\text { Protein kinase }\end{array}$ \\
\hline Defense & $\begin{array}{l}\text { Secoisolariciresinol dehydrogenase } \\
\text { Pin2 gene, wound induced } \\
\text { Class III acidic endochitinase } \\
\text { Chitinase } 2 \\
\text { Class III peroxidase (pod3) } \\
\text { Secretory peroxidase (prx) } \\
\text { Metallothionein } \\
\text { Pathogenesis-related protein PR10A } \\
\text { Pathogenesis-related protein 4A } \\
\text { Beta-1,3-glucanase }\end{array}$ \\
\hline Abiotic stimuli and development & $\begin{array}{l}\text { FAR1 (far-red impaired response 1) } \\
\text { Auxin-repressed protein } \\
\text { Auxin-induced protein } \\
\text { Putative ripening-related protein }\end{array}$ \\
\hline Miscellaneous & $\begin{array}{l}\text { Early light inducible protein } \\
\text { Tumor-related protein } \\
\text { Putative } 33-k D a \text { secretory protein } \\
\text { Protein involved in starch metabolism }\end{array}$ \\
\hline
\end{tabular}

The gene expression of MT presupposes a strategy adopted by G. americana to tolerate and accumulate high concentrations of $\mathrm{Cd}$ in its root system. MTs are heavy metal-binding proteins of low molecular weight and contain 45 to 85 amino acids (Almeida et al., 2007). The MTs in plants have been consistently related to tolerance to and homeostasis of $\mathrm{Cu}$, whereas phytochelatins are related to the protection of plants from the toxic effects of $\mathrm{Cd}$ (Cobbett and Golds- 
Table 2. Probable identifications of the most abundant sequences in the cDNA library induced by cadmium.

\begin{tabular}{lccc}
\hline Functional annotation & No. of ESTs & E-value & Size of the sequences (bp) \\
\hline Metallothionein (MT) & 14 & $1.10^{-17}-4.10^{-4}$ & $294-827$ \\
Metallothionein IV (MT IV) & 2 & $3.10^{-15}-1.10^{-8}$ & $367-379$ \\
PR4 & 3 & $8.10^{-50}-5.00^{-40}$ & $316-857$ \\
PR10 & 2 & $2.10^{-34}-9.10^{-32}$ & $478-578$ \\
Protein involved in starch metabolism & 2 & $2.10^{-87}-2.10^{-5}$ & $396-549$ \\
Ribosomal RNA & 3 & $3.00^{-79}-8.10^{-40}$ & $358-792$ \\
\hline
\end{tabular}

ESTs $=$ expressed sequence tags.

brough, 2002). For Arabidopis, gene silencing experiments revealed that MT1 was required to protect this species against the toxic effects of $\mathrm{Cd}$, and that it may be specifically related to the reduction and control of toxic levels of such metal in cells (Zimeri et al., 2005). In addition, one MT1, when isolated from a cDNA library induced by $\mathrm{Cu}$ in Festuca rubra, showed tolerance to $\mathrm{Cd}$ in studies of functional complementation using vectors with cDNA MT1 (Ma et al., 2003). Furthermore, transformation of Nicotiana tabacum with an MT gene, isolated from Silene vulgaris, increased tolerance to and accumulation of $\mathrm{Cd}$ in such species (Gorinova et al., 2007).

The PR proteins occur in a wide variety of plant species, whose induction usually follows the development of a local or systemic resistance after infection by a great number of pathogens (Freitas et al., 2003). The effect of $\mathrm{Cd}$ in plant species mimics the response of plants to pathogen attack, in that an increase in reactive oxygen species is observed, followed by reactions of secondary defenses (Schützendübel and Polle, 2002).

\section{CONCLUSIONS}

Although preliminary, the data from ESTs through the construction of a cDNA library of $G$. americana roots provided the first identification of putative genes associated with metallothioneins, peroxidases and other proteins and enzymes related to defense mechanisms for this species. These genes are common in plants that are submitted to biotic and abiotic stress. Further EST studies may help determine and characterize gene functions expressed during exposure of G. americana to Cd.

\section{ACKNOWLEDGMENTS}

We gratefully acknowledge the financial support provided by FAPESB (Fundação de Amparo à Pesquisa do Estado da Bahia) and UESC (Universidade Estadual de Santa Cruz). V.L. Souza was supported by CNPq (Conselho Nacional de Pesquisa).

\section{REFERENCES}

Almeida A-AF, Valle RR, Mielke MS and Gomes FP (2007). Tolerance and prospection of phytoremediator woody species of Cd, $\mathrm{Pb}, \mathrm{Cu}$ and Cr. Braz. J. Plant Physiol. 19: 83-98.

Barbosa RMT, Almeida A-AF, Mielke MS, Loguercio LL, et al. (2007). A physiological analysis of Genipa americana L.: A potential phytoremediator tree for chromium polluted watersheds. Environ. Exp. Bot. 61: 264-271.

Chaoui A and El Ferjani E (2005). Effects of cadmium and copper on antioxidant capacities, lignification and auxin degradation in leaves of pea (Pisum sativum L.) seedlings. C. R. Biol. 328: 23-31. 
Cobbett C and Goldsbrough P (2002). Phytochelatins and metallothioneins: roles in heavy metal detoxification and homeostasis. Annu. Rev. Plant Biol. 53: 159-182.

Covitz PA, Smith LS and Long SR (1998). Expressed sequence tags from a root-hair-enriched Medicago truncatula cDNA library. Plant Physiol. 117: 1325-1332.

Dickinson NM and Pulford ID (2005). Cadmium phytoextraction using short-rotation coppice Salix: the evidence trail. Environ. Int. 31: 609-613.

Freitas LB, Koehler-Santos P and Salzano FM (2003). Pathogenesis-related proteins in Brazilian wheat genotypes: protein induction and partial gene sequencing. Cienc. Rural 33: 497-500.

Gesteira AS, Michelli F, Ferreira CF and Cascardo JC (2003). Isolation and purification of functional total RNA from different organs of cacao tree during its interaction with the pathogen Crinipellis perniciosa. BioTechniques 35: 494-500.

Gorinova N, Nedkovska M, Todorovska E, Simova-Stoilova L, et al. (2007). Improved phytoaccumulation of cadmium by genetically modified tobacco plants (Nicotiana tabacum L.). Physiological and biochemical response of the transformants to cadmium toxicity. Environ. Pollut. 145: 161-170.

Hoagland DR and Arnon DI (1950). The water-culture method for growing plants without soil. California Agricultural Experiment Station, Berkeley.

Journet EP, van Tuinen D, Gouzy J, Crespeau H, et al. (2002). Exploring root symbiotic programs in the model legume Medicago truncatula using EST analysis. Nucleic Acids Res. 30: 5579-5592.

Ma M, Lau P, Jia Y-T, Tsang W-K, et al. (2003). The isolation and characterization of type 1 metallothionein (MT) cDNA from a heavy-metal-tolerant plant, Festuca rubra cv. Merlin. Plant Sci. 164: 51-60.

Mielke MS, Almeida A-AF, Gomes FP, Aguilar MAG, et al. (2003). Leaf gas exchange, chlorophyll fluorescence and growth responses of Genipa americana seedlings to soil flooding. Environ. Exp. Bot. 50: 221-231.

Sambrook J, Fritsch EF and Maniatis T (1989). Molecular Cloning: A Laboratory Manual. 2nd edn. Cold Spring Harbor Press, New York.

Schützendübel A and Polle A (2002). Plant responses to abiotic stresses: heavy metal-induced oxidative stress and protection by mycorrhization. J. Exp. Bot. 53: 1351-1365.

Zhang L, Ma XL, Zhang Q, Ma CL, et al. (2001). Expressed sequence tags from a NaCl-treated Suaeda salsa cDNA library. Gene 267: 193-200.

Zimeri AM, Dhankher OP, McCaig B and Meagher RB (2005). The plant MT1 metallothioneins are stabilized by binding cadmiums and are required for cadmium tolerance and accumulation. Plant Mol. Biol. 58: 839-855. 